\title{
Verklarende lys van terme wat in houtanatomie gebruik word
}

J.P.J. Swart en J.J.A. van der Walt

Departement Plantkunde, Universiteit van Stellenbosch

Pas nadat die International Association of W'ood Anatomists (IAWA) in 1930 gestig is, is daar in spesiale komitee alangewys om 'n lys van terme wat in houtanatomie gebruik word, op te stel. Hierdie lys het in 1933 in die tydsk rif Tropical W'oods (nr. 36) verskyn. Die lys is daarna hersien. in verskeie tale vertaal, en versk yn in 1964 in boekvorm met die titel: Multilingual glossary. of terms used in wood anatoml.

Met die samestelling van die Afrikaanse woordelys, is vrylik van die 1964 veeltalige lys gebruik gemalak en die nommers tussen hakies by die terme verwys na die nommers in die veeltalige lys. "n Groot persentasie van die terme in die Afrikaanse woordelys kom glad nie in die Plantkundewoordeboek (1972) van die Suid-Afrikaanse Akademie vir Wetenskap en Kuns voor nie.

Terme in die woordelys wall deur 'n nommer in hakies gevolg word, is die eerste keuse in Afrikaans. Die term word deur 'n definisie gevolg. Sinonieme is kursief gedruk en van die nodige kruisverwysings voorsien.

Ons verwelkom kommentaar en hoop dat ons met hierdie lys 'n bydrac kan makk tot die uitbouing van die Afrikaanse vaktaal.

\section{BAS (1)}

'n Tegniese term vir die weefsels wat by stamme aan die buitekant van die valatkambium voorkom. In ouer bome kan twee dele onderskei word: 'n binneste, lewende laag (sien FI.OËE.MI) en 'n buitenste, dooie laag (sien RH)TIDOOM).

Bark *(E) Bast* $(\mathrm{N})$ Rinde *(D)

\section{BAS, HARIDE (3)}

Die gedeelte van die bas wat uit sklerenchiem bestaan. Soms word hierdie elemente binne 'n groeiring in konsentriese sones met sagte bas afgewissel. in Laag harde bas wat aan die einde van die groeiseisoen gevorm is. staan as die terminaallaag bekend.

Bark. hard *(E) Bast, harde *(N) Bast. Hart- *(D)

BAS, LAAT- (4)

Bas wat aan die einde van in groeiperiode gevorm word (sien HOLT, LAAT-). Dit bestaan hoofsaaklik uit parenchiem en enkele sifvate of sifselle met klein deursneë. Aan die einde van 'n groeiperiode word soms in terminaallaag bestaande uit vesels (sien BAS, HARDE), gevorm.

$$
\text { Bark, late }{ }^{*}(\mathrm{E}) \text { Bast, late }{ }^{*}(\mathrm{~N}) \text { Bast, Spä̈- }{ }^{*}(\mathrm{D})
$$

\section{BASPARENCHIEM SiE PARENCHIEM, F.I.OËE.II-}

*(E): Engels; *(N): Nederlands: *(D): Duits

\section{BAS, SAGTE (5)}

Dié gedeelte van die bas wat uit sifvate, begeleidende selle. parenchimatiese- en verkurkte selle bestaan sonder enige sklerenchiem. Kom as konsentriese lae afwisselend met harde bas voor of vorm die grondweefsel waarin harde basselle onreëlmatig verspreid voorkom.

Bark, soft ${ }^{*}(\mathrm{E}) \quad$ Bast. zachte ${ }^{*}(\mathrm{~N}) \quad$ Bast,

Weich- ${ }^{*}(\mathrm{I})$

\section{BAS, VROË̈. (2)}

Die bas wat aan die begin van 'n groeiperiode gevorm word (sien IIOUT, VROEË).

Bark, early ${ }^{*}(\mathrm{E}) \quad$ Bast, vroege ${ }^{*}(\mathrm{~N})$ Bast,

Erüh- *(I))

\section{BASSTRAAL Sien STRAAI.}

\section{BEGEI.EIIDENDE SEL (14)}

in Parenchiemsel in die floëem van die angiospermac wat 'n gemeenskaplike oorsprong met 'n sifvatelement het en wat geassosieerd daarmee voorkom. 'n Begeleidende sel het 'n opvallende nuk leus en 'n digte sitoplasma-inhoud. maar geen of klein vakuole. 'n Begeleidende sel kan tydens differensiasie een of meer dwarsdelings ondergaan.

Companion cell *(E) Begeleidende cel ${ }^{*}(\mathrm{~N})$

Geleitzelle *(I))

\section{BEKIEDE STIPPEL.S Sien STIPPEI}

\section{BRAGISKLEREÏEDE Sien STEENSEI.}

\section{DROES Sien KRISTALI.E}

\section{EINIDWANI) (27)}

'n Term wat in houtanatomie gebruik word vir: (1) Dic wand wat loodreg op die lengte-as van in parenchimatiese sel staan, d.w.s. of die tangensiale wand van 'n straalparenchiemsel of die dwarswand van in aksiale parenchiemsel. (2) Die skuins- of dwarswand tussen twee houtvatelemente (die kontakvlak tussen twee opeenvolgende houtvatelemente).

End wall ${ }^{*}(E)$ Findwand ${ }^{*}(N)$ Fndwand $*(D)$

EINDWAND, KRAAINOR.IIG; VERDIKTE (28)

Die eindwand van 'n xileemparenchiemsel wal in 'n dwarssnee soos in string krale vertoon weens die stippels wat daarin voorkom.

End wall nodular ${ }^{*}(\mathrm{E})$ Findwand met knobbeltjes *(N) Endwand mit Knötchen *(D)

\section{ELE.MIENT (23)}

Algemene term vir 'n indiwiduele sel. 'n Houtvat bestaan byvoorbeld uit 'n aantal selke of houtvatelemente.

Flement *(F) Flement * $(\mathrm{N})$ filement $*(\mathrm{D})$ 
ELEMENTE, AKSIALE (24)

Alle elemente wat deur die spoelvormige inisiaalselle van die vaatkambium gevorm word en dus deel vorm van die aksiale sisteem. Die elemente is met hul lang-as parallel tot die lang-as van die orgaan georiënteer.

Elements, axial ${ }^{*}(\mathrm{E}) \quad$ Elementen, axiale ${ }^{*}(\mathrm{~N})$

Elemente, Axiale *(D)

ELEMENTE, GESTRATIFISEERDE (26)

Selle wat in tangensiale sneë duidelik in horisontale lae gerangskik is.

Elements, storied ${ }^{*}(\mathrm{E}) \quad$ Elementen, in etages ${ }^{*}(\mathrm{~N})$

Elemente, Stockwerk(-artige) *(D)

\section{ELEMENTE, KONGENERIESE (25)}

Selle van dieselfde anatomiese tipe.

Elements, congeneric $*(E) \quad$ Elementen, congenitale

$*(\mathrm{~N})$ Elemente gleichartiger Differenzierung *(D)

\section{EPIDERMIS (29)}

Die buitenste sellaag van 'n primêre plantliggaam. Die buitenste selwande is dikwels verdik en met kutien deurtrek. Bestaan soms uit meer as een sellaag. Die buitenste wand is meestal met ' $n$ kutikula bedek.

Epidermis * $(\mathrm{E}) \quad$ Epidermis ${ }^{*}(\mathrm{~N}) \quad$ Epidermis ${ }^{*}(\mathrm{D})$

\section{EPITEELLAAG (31)}

Die parenchimatiese laag sekreetselle wat ' $n$ intersellulêre kanaal of holte omring of uitvoer.

Epithelium *(E) Epithelium * ${ }^{*}(N)$ Epithel *(D)

\section{EPITEEISEL (30)}

'n Enkele sel van die epiteellaag.

Epithelial *(E) Epitheelcel *(N) Epithelzelle *(D)

\section{FELLLEM (99)}

Sekondêre weefsel wat in stingels en wortels na buite deur die fellogeen gevorm word. Die selwande is gewoonlik met suberien deurtrek (verkurk). Dikwandige felleemselle kan ook gelignifiseerde sellae naby die sellumen insluit. Onverkurkte selle van die felleem staan bekend as fellö̈ede (Sien PERIIDERM). Sinoniem: Kurk.

Phellem *(E) Felleem *(N) Phellem *(D)

\section{FELI.ODERM (100)}

Sekondêre weefsel wat na binne deur die fellogeen gevorm word. In houtagtige plante kan hierdie selle aansienlik vergroot, dik wande ontwikkel en steenselle vorm. I ie selle is dikwels in 'n radiale rigting gestrek. Sinonicm: Sekondêre korteks.

Phelloderm *(E) Felloderm *(N) Phelloderm *(D)

\section{FELI.OCEEN (101)}

'n Meristimatiese sellaag wat die periderm vorm. Sinoniem: Kurkkambium.

Phellogen ${ }^{*}(\mathrm{E}) \quad$ Fellogeen $*(N)$ Phellogen $*(D)$

FIBRIL. (39)

in Draadvormige struktuurelement van sellulose wat in selwande met 'n ligmikroskoop sigbaar is. Opmer- king: Wanneer hierdie term ongekwalifiseerd gebruik word. impliseer dit "makrofibril", in teenstelling met die elektronmikroskopiese term "mikrofibril".

Fibril ${ }^{*}(\mathrm{E}) \quad$ Fibril ${ }^{*}(\mathrm{~N}) \quad$ Fibrille $*(\mathrm{D})$

\section{FIBRILHOEK (40)}

Die hoek tussen die lengte-as van 'n sel en die rigting waarin die fibrille in die selwand georiënteer is.

Fibril angle ${ }^{*}(\mathrm{E})$ Fibrilhoek ${ }^{*}(\mathrm{~N})$ Fibrillenwinkel ${ }^{*}(\mathrm{D})$

\section{FLOËEM (102)}

Die belangrikste weefsel van vaatplante vir die vervoer van organiese voedingstowwe. Dit word ò as primêre of as sekondêre weefsel gevorm en is met die xileem geassosieer. Die primêre floëem differensieer uit die prokambium en die sekondêre floëem word deur die vaatkambium gevorm. Die basiese seltipes van die floëem sluit sifelemente (sifvate of sifselle), begeleidende selle, parenchimatiese selle, vesels en sklereïede in. Phloem * ${ }^{*}$ E) Floëem * ${ }^{*}(\mathrm{~N})$ Phloem *(D)

\section{FLOËEM, BINNE- (104)}

Primêre floëem aan die murg se kant van die primêre xileem (kom slegs by ' $\mathrm{n}$ aantal plantfamilies voor). Sinoniem: Intraxilêre floëem.

Phloem, internal ${ }^{*}(\mathrm{E}) \quad$ Floëem, binnen- ${ }^{*}(\mathrm{~N})$ Phloem. Markständiges *(D)

\section{FLOËEM, INGESLOTE (103)}

Floëemstringe of -lae wat in die sekondêre xileemsilinder van 'n aantal plantfamilies ingesluit is. Sinoniem: Interxilêre floëem.

Phloem, included *(E) Floëem, ingesloten * $(N)$ Phloem, Eingeschlossenes *(D)

\section{FLOËEM, INTERXILERE Sien FLOËEM, INGE- SI.OTE}

\section{FLOËEM, INTRAXILÊRE Sien FLOËEM, BINNE-}

\section{FLOËEM, PRIMÊRE (105)}

Die eerste gevormde floëem wat deur die apikale meristeme van stingels en wortels gevorm word. Dit differensieer uit die buitenste selle van die prokambium. voordat ' $n$ duidelike vaatkambium ontwikkel het.

Phloem. primary ${ }^{*}(\mathrm{E}) \quad$ Floëem, primair ${ }^{*}(\mathrm{~N})$ Phloem, Primäres *(D)

\section{FLOËEM, SEKONDÊRE (106)}

Dit is floëem wat deur die vaatkambium gevorm word in 'n stadium wanneer die primêre floëem reeds bestaan (sien FLOËEM).

Phloem, secondary *(E) Floëem, secundair * $(N)$ Phloem. Sekundäres *(D)

\section{FLOËEMMOEDERSEI.LE (107)}

Selle wat deur spoelvormige inisiaalselle van die vaatkambium na buite gevorm word. Die selle ondergaan soms periklinale seldelings en differensieer geleidelik tot floëemelemente.

Phloem mother cells * $(\mathrm{E}) \quad$ Flö̈emmoedercellen ${ }^{*}(\mathrm{~N})$ Phloem-Mutterzellen ${ }^{*}(\mathrm{D})$ 


\section{GESTRATIFISEERDE ELEMENTE (162)}

'n Term wat beide die gelaagdheid van aksiale elemente asook die strale op die tangensiale vlak beskryf. Die lae is dikwels met die blote oog as fyn strepies waarneembaar. Sinoniem: Riffelmerke.

Ripple marks ${ }^{*}(\mathrm{E})$ Etagebouw ${ }^{*}(\mathrm{~N}) \quad$ Streltung, Horizontale *(D)

\section{GOMGANG Sien INTERSELLULÊRE KANAAL}

GOMKANAAL (43)

Intersellulêre kanaal waarin gomagtige stowwe afgeskei word.

Gum duct *(E) Gomgang *(N) Gang, Gummiführender *(D)

\section{GROEIRING (159)}

'n Hout- of baslaag wat klaarblyklik tydens een groeiperiode gevorm is. In dwarssneë van hout vanaf gematigde klimaatstreke kan vroeë en laathout asook vroeë en laatbas gewoonlik onderskei word. Sinoniem: Groeisone.

Ring, growth ${ }^{*}(\mathrm{E}) \quad$ Groeiring ${ }^{*}(\mathrm{~N}) \quad$ Zuwachsring ${ }^{*}(\mathrm{D})$

\section{GROEIRING, ONDERBROKE (156)}

'n Groeiring wat nie oor die hele omtrek van die stam voorkom nie.

Ring, discontinuous growth ${ }^{*}(\mathrm{E})$ Groeiring, onderbroken $*(\mathrm{~N}) \quad$ Zuwachsring, Auskeilender *(D)

\section{GROEIRINGGRENS (161)}

Die buitenste grens van die groeiring.

Ring boundary, growth * $(\mathrm{E})$ Groeiringgrens ${ }^{*}(\mathrm{~N})$

Zuwachsringgrenze ${ }^{*}(\mathrm{D})$

\section{GROEISONE (42) Sien GROEIRING}

\section{HARSGANG Sien HARSKANAAL}

HARSKANAAL (153)

'n Intersellulêre kanaal waarin harsagtige stowwe afgeskei word. Sinoniem: Harsgang.

Resin canal ${ }^{*}(\mathrm{E}) \quad$ Harsgang $*(\mathrm{~N})$ Harzkanal $*(\mathrm{D})$

\section{HOFSTIPPEL Sien STIPPEL}

\section{HOFSTIPPELPAAR Sien STIPPELPAAR, HOF-}

\section{HOUT (192)}

Die belangrikste weefsel in blare, stingels en wortels vir die vervoer van water en minerale stowwe asook vir die verlening van meganiese sterkte aan die organe. Bestaan uit trageale elemente (houtvate en trageiede), xileemvesels, aksiale parenchiem en xileemstrale. Sinoniem: Xileem.

Wood $*(\mathrm{E}) \quad$ Hout $*(\mathrm{~N}) \quad$ Holz $*(\mathrm{D})$

\section{HOUT MET HOUTVATE (199)}

Kenmerkend van die meeste houtagtige Dicotyledoneae. In teenstelling met die Gymnospermae waar houtvate ontbreek (sien HOUT SONDER HOUTVATE).

Wood, pored ${ }^{*}(\mathrm{E})$ Hout met vaten ${ }^{*}(\mathrm{~N})$ Holz mit Poren *(D)

\section{HOUT SONDER HOUTVATE (198)}

Hout sonder houtvate. Kenmerkend van die meeste Gymnospermae (sien HOUT MET HOUTVATE).

Wood, non-pored *(E) Hout zonder vaten $*(N)$ Holz ohne Poren (Porenfrei) ${ }^{*}(\mathrm{D})$

HOUT, DRUK- (193)

Reaksiehout wat veral aan die onderkant (verhoogde druksterktegebied) van takke en oorhangende of krom stamme van Gymnospermae-hout voorkom. In dwarssneë word dit gekenmerk deur trageiede met 'n ronde voorkoms, selwande wat sterk gelignifiseer is en waarin daar spiraalgerangskikte skeurtjies voorkom. Drukhout het opvallend hoër digthede as die omringende weefsel. Sinoniem: Pershout (sien HOUT, TREK-).

Wood, compression ${ }^{*}(\mathrm{E}) \quad$ Hout, druk- ${ }^{*}(\mathrm{~N})$ Holz, Druck- ${ }^{*}(\mathrm{D})$

\section{HOUT, HALFRINGPORIGE (202)}

Hout waarvan die vroeëhout kenmerkend uit òf 'n sone met slegs enkele, groot houtvate òf 'n sone met 'n groot aantal kleiner houtvate bestaan.

Wood, semi-ring-porous ${ }^{*}(\mathrm{E})$ Hout, half of semi$(\mathrm{k})$ ringporig ${ }^{*}(\mathrm{~N})$ Holz, Halbringporiges *(D)

\section{HOUT, LAAT- (197)}

Die laasgevormde hout binne die groeiring met die grootste digtheid en selle wat dik wels gekenmerk word deur' $n$ kleiner lumen.

Wood, late *(E) Hout, laat- ${ }^{*}(\mathrm{~N}) \quad$ Holz, Spät- ${ }^{*}(\mathrm{D})$

\section{HOUT, OORGANGS- (196)}

Die binneste (oudste) gedeeltes van spinthout wat ten opsigte van kleur en algemene kenmerke 'n oorgang tussen spint- en kernhout vorm.

Wood, intermediate ${ }^{*}(\mathrm{E})$ Hout, intermediair ${ }^{*}(\mathrm{~N})$

Holz, Intermediäres *(D)

\section{HOUT, REAKSIE- (200)}

Hout wat anatomies in ' $\mathrm{n}$ mindere of meerdere mate van normale hout afwyk. Kom veral voor in leunende en krom stamme en takke. Moet beskou word as 'n natuurlike reaksie van die plant om deur middel van die groeiproses na die normale toestand en posisie terug te keer. Opmerking: By Dicotyledoneae bestaan dit uit trekhout en by Gymnospermae uit drukhout.

Wood, reaction ${ }^{*}(\mathrm{E})$ Hout, reactie ${ }^{*}(\mathrm{~N}) \mathrm{Holz}$,

Reaktions- ${ }^{*}(\mathrm{D})$

\section{HOUT, RINGPORIGE (201)}

Hout waarvan die vroeë hout se houtvate duidelik groter as dié van die laathout is, terwyl dit ook in duidelik waarneembare sones of ringe voorkom (sien HOIIT, VERSPREIDPORIGE)

Wood. ring-porous ${ }^{*}(\mathrm{E})$ Hout, kringporig ${ }^{*}(\mathrm{~N})$ Holz, Ringporiges *(D) 


\section{HOUT, SOMER-Sien HOUT, LAAT-}

HOUT, TREK- (203)

Reaksiehout wat aan die boonste gedeelte van takke en geboë of skeefstaande stamme van Dicotyledoneaehout gevorm word. Anatomies herkenbaar aan min of geen lignifikasie, en 'n gelatienlaag in die vesels se selwande (sien HOUT, DRUK-).

Wood, tension ${ }^{*}(\mathrm{E}) \quad$ Hout, trek- ${ }^{*}(\mathrm{~N}) \quad$ Holz, Zug- *(D)

\section{HOUT, VERSPREIDPORIGE (194)}

Hout met houtvate wat oor die hele groeiring ongeveer dieselfde grootte het of waar die houtvate se afmetings min verander. Die houtvate kom ook reëlmatig verspreid oor die hele groeiring voor.

Wood, diffuse-porous ${ }^{*}(\mathrm{E})$ Hout, verspreidporig

*(N) Holz, Zerstreutporiges *(D)

\section{HOUT, VOORJAARS- Sien HOUT, VROEË-}

\section{HOUT, VROEË (195)}

Die minder digte, eerste gevormde hout van 'n groeiring. Hiedie selle besit groot lumens.

Wood, early ${ }^{*}(\mathrm{E}) \quad$ Hout, vroeg ${ }^{*}(\mathrm{~N}) \quad$ Holz,
Früh- ${ }^{*}(\mathrm{D})$

\section{HOUTSTRAAL Sien STRAAL}

\section{HOUTVAT (189)}

'n Aksiale buis van onbepaalde lengte wat ontstaan deur die samesmelting van 'n reeks aksiale selle - die houtvatelemente. Die eindwande van die houtvatelemente het tydens differensiasie gedeeltelik of geheel gedegenereer en vorm die perforasieplate. Houtvate is deur middel van hofstippels met kongeneriese elemente in verbinding.

Vessel $^{*}(\mathrm{E}) \quad$ Vat $^{*}(\mathrm{~N})$ Gefäss *(D)

\section{HOUTVAT, ALLEENSTAANDE (133)}

'n Houtvat wat geheel en al deur ander houtelemente omring word.

Pore, solitary *(E) Vat, alleenstaand * $(\mathbf{N})$ Pore, Solitäres ${ }^{*}(\mathrm{D})$

\section{HOUTVATEL.EMENT (190)}

Een van die aksiale, sellulêre elemente van 'n houtvat (sien HOUTVAT).

Vessel member or element *(E) Vatlid of -element *(N) Gefässglied (odor Gefässelement) *(D)

\section{HOUTVATELEMENT, VESEI.VORMIGE (I91)}

'n Klein deursnee houtvatelement wat heelwat ooreenkomste met veseltrageiede toon.

Vessel element or member. (Fibriform) *(E) Vatelement of -lit, vezelvormig of onvolledig ${ }^{*}(\mathrm{~N})$ Gefässglied odor -element. Faserförmiges *(I))

\section{HOL'TVATGROEP (135)}

'n Groepie van twee of meer houtvate wat bymekaar voorkom. Die aangrensende (gemeenskaplike) selwan- de is reguit sodat dit die indruk skep van 'n alleenstaande houtvat wat onderverdeel is. Opmerking: Die algemeenste tipe is radiale groepe, d.w.s. waar houtvate in radiale rye voorkom met reguit, tangensiale selwande tussenin. 'n Ander algemene tipe is wanneer houtvate in onreëlmatige groepe gerangskik is.

Pore, multiple ${ }^{*}(\mathrm{E})$ Vatgroep ${ }^{*}(\mathrm{~N})$ Poren, Vielfach- ${ }^{*}(\mathrm{D})$

\section{HOUTVATREEKS (134) \\ 'n Reeks nie-aangrensende, alleenstaande houtvate. Pore chain ${ }^{*}(\mathrm{E})$ Vatreeks ${ }^{*}(\mathrm{~N})$ Porenkette ${ }^{*}(\mathrm{D})$}

\section{HOUTVESEL Sien XILEEMVESEL}

\section{IDIOBLAST (45)}

'n Sel waarvan die vorm of inhoud duidelik van die ander elemente in dieselfde weefsel verskil. Opmerking: Voorbeelde in hout is kristalhoudende selle, olieselle en slymselle.

Idioblast ${ }^{*}(\mathrm{E}) \quad$ Idioblast * $(\mathrm{N}) \quad$ Idioblast *(D)

\section{INKEPING (46)}

'n Smal groef in straalparenchiemselle waar die horisontale wand met die tangensiale (eind)-wand saamsmelt. Radiaal is dit sigbaar as 'n groef naby die punt waar die horisontale en tangensiale wande ineenloop. Opmerking: Slegs van toepassing op hout van die Gymnospermae.

Indenture ${ }^{*}(\mathrm{E}) \quad$ Inkeping ${ }^{*}(\mathrm{~N}) \quad$ Einkerbung ${ }^{*}(\mathrm{D})$

\section{INTERSELLULERE HOLTE (50) Sien INTERSEL- LULERE RUIMTE}

\section{INTERSELLULERE KANAAL (47)}

Buisvormige, intersellulêre holte van onbepaalde lengte waarin hars of gom deur epiteelselle afgeskei word. Die kanaal kan (1) aksiaal of (2) radiaal (in straal) verloop (sien INTERSELLULERE RUIMTE). Sinonieme: Harskanaal, gomkanaal en gomgang.

Intercellular canal ${ }^{*}(\mathrm{E}) \quad$ Intercellulaire gang ${ }^{*}(\mathrm{~N})$ Interzellulargang ${ }^{*}(\mathrm{D})$

\section{INTERSELLULERE KANAAL, RADIALE (48)}

'n Kanaal wat horisontaal ten opsigte van die plant se lengte-as in 'n radiale rigting verloop.

Intercellular canal, radial ${ }^{*}(\mathrm{E})$ Intercellulaire gang, radiale *(N) Interzellulargang, Radialer *(D)

\section{INTERSELLULERE KANAAL, TRAUMATIESE} (49)

'n Kanaal wat gevorm word in reaksie op 'n wond aan die lewende stam. Opmerking: Hierdie kanaal is dikwels abnormaal groot en kan in sowel die aksiale of radiale rigtings ontwikkel.

Intercellular canal, traumatic *(E) Intercellulaire gang, traumatische ${ }^{*}(\mathrm{~N})$ Interzellulargang. Traumatischer ${ }^{*}(\mathrm{D})$

INTERSELLCLERE LAAG Sien MIDDELL.AMEI.L.A 


\section{INTERSELLULERE RUIMTE (52)}

'n Ruimte tussen selle. Twee tipes word onderskei: (1) 'n Intersellulêre ruimte waarin hars, gom, melksap, ens. afgeskei word, of (2) 'n Intersellulêre ruimte wat skisogeen of lisigeen ontstaan het en waarin geen stowwe afgeskei word nie. Sinoniem: Interstisiële ruimte.

Intercellular space *(E) Intercellulaire ruimte ${ }^{*}(\mathrm{~N})$

Interzellularer Raum *(D)

\section{INTERSTISIËLE RUIMTE (53)}

Verouderde term vir die ruimte tussen die selle waarin geen stowwe afgeskei word nie (sien INTERSELLULERE RUIMTE).

Interstitial space *(E) Interstitiële ruimte ${ }^{*}(\mathrm{~N}) \quad$ Institialraum *(D)

\section{JAARRING (155)}

Die sekondêre weefsel wat gedurende een jaar in die hout en/of die bas gevorm word. (sien GROEIRING). Kan in dwarssneë waargeneem word wanneer die samestelling van die vroeë en laathout verskil.

Ring, annual *(E) Jaarring *(N) Jahrring *(D)

JAARRING, MEERVOUDIGE Sien JAARRING, SAAMGESTELDE.

\section{JAARRING, ONVOLLEDIG Sien JAARRING, VALS.}

\section{JAARRING, SAAMGESTELDE (157)}

'n Jaarring wat uit twee of meer groeiringe bestaan. Ring, double (or multiple) *(E) Jaarring, dubbele (of meervoudige) * $(\mathrm{N})$ Jahrring, Doppelter (oder Vielfacher) ${ }^{*}(\mathrm{D})$

\section{JAARRING, VALS (158)}

'n Indiwiduele groeiring of gedeelte van 'n groeiring van 'n saamgestelde jaarring.

Ring, false annual *(E) Jaarring, onvolledige

*(N) Jahrring, Falscher *(D)

\section{JAARRINGGRENS}

Die buitenste kant (verste van murg) van 'n jaarring. Annual ring boundary ${ }^{*}(\mathrm{E})$ Jaarringgrens ${ }^{*}(\mathrm{~N})$ Jahrringgrense *(D)

\section{KALLITRISOÏEDE VERDIKKING (6)}

Pare verdikkingsbalkies wat oor die hofstippels van trageïede voorkom.

Callitrisoid thickening * $(\mathrm{E})$ Callitrisoïde verdikking ${ }^{*}(\mathrm{~N})$ Callitrisoide Verdickung *(D)

\section{KAMBIUM (9)}

'n Aktiefdelende laag selle wat deur periklinale delings aan sekondêre weefsels oorsprong gee. Opmerking: Twee kambiums, die vaatkambium en fellogeen word onderskei.

Cambium *(E) Cambium * $*$ N) Kambium *(D)

\section{KAMBIUMINISIAAL (7)}

'n Indiwiduele kambiumsel. Spoelvormige en straalinisiaalselle word in die vaatkambium onderskei.
Cambial initial *(E) Cambialinitiaal *(N) Kambiuminitiale *(D)

\section{KAMBIUMSONE (8)}

'n Benaming vir die sone wat uit kambiumselle en ongedifferensieerde kambiumderivate "bestaan. Die breedte van hierdie sone kan aansienlik varieer.

Cambium zone ${ }^{*}(\mathrm{E})$ Cambiale zone ${ }^{*}(\mathrm{~N})$ Kambialzone *(D)

\section{KERNHOUT (44)}

Die binneste lae hout van 'n groeiende boom wat uit nie-lewende selle bestaan, en waarvan die reserwe stowwe (bv. setmeel) of onttrek is of in kernhoutstowwe omgesit is. Gewoonlik is kernhout donkerder van kleur as spinthout. Soms is dit baie moeilik om tussen die twee te onderskei. Sinoniem: Duramen (sien SPINTHOUT).

Heartwood *(E) Kernhout *(N) Kernholz *(D)

\section{KORTEKS (17)}

Die primêre grondweefsel van 'n stingel of wortel tussen die epidermis of felleem en die vaatweefsel of perisikel.

Cortex ${ }^{*}(\mathrm{E}) \quad$ Cortex ${ }^{*}(\mathrm{~N}) \quad$ Cortex ${ }^{*}(\mathrm{D})$

\section{KRASSULA (18)}

Horisontaal (dwars, reguit of half-sirkelvormige) georiënteerde verdikkings naby hofstippels van veral die trageïede aan die einde van die vroeë hout van sommige Gymnospermae. Die ongelignifiseerde verdikkings word gevorm deur materiaal van die intersellulêre laag en primêre selwand. Sinoniem: Lyste(s) van Sanio.

Crassula $(\mathrm{e}){ }^{*}(\mathrm{E})$ Crassula(e) ${ }^{*}(\mathrm{~N})$ Crassulae, Bälklein ${ }^{*}(\mathrm{D})$

\section{KRISTALHOUDENDE SEL (21)}

'n Sel met een of meer kristalle daarin. Opmerking: Radiale en aksiale parenchiemselle bevat dikwels groot hoeveelhede kristalle.

Crystalliferous cell *(E) Kristalhoudende cel ${ }^{*}(N)$ Kristallführende Zelle *(D)

\section{KRISTALHOUDENDE SELREEKS (22)}

'n Reeks kristalhoudende selle wat deur die vorming van septums uit dieselfde moedersel ontstaan het.

Crystalliferous cell, chambered * $(E) \quad$ Kristalcellenvezel ${ }^{*}(\mathrm{~N}) \quad$ Faser, Kristallkammer- ${ }^{*}(\mathrm{D})$

\section{KRISTALLE (20)}

Die volgende vorme word onderskei:

Droes: in Stervormige kristalaggregaat, soms met 'n kern van organiese stowwe. Kan deur middel van 'n steeltjie aan die selwand vasgeheg of los in die sel wees.

Kristalsand/-gruis: 'n Korrelrige massa wat bestaan uit klein, fyn kristalle.

Kristalsferiet: in Bolvormige versameling van uiters fyn, naaldvormige kristalle.

Rafeïede: dels voorkom. 
Stiloïede: $\quad$ 'n Lang, kolomvormige kristal waarvan die lengte ongeveer vier maal die breedte is. Met spits of stomp punte.

Crystal *(E) Kristal *(N) Kristall *(D)

\section{KRUISINGSVELD (19)}

'n Term vir die reghoek wat gevorm word deur die wande van straalselle (radiaal) en aksiale trageïede soos op die radiale vlak waargeneem. Word hoofsaaklik vir die hout van Gymnospermae gebruik.

Cross-field *(E) Kruisingsveld * $(\mathrm{N}) \quad$ Kreuzungsfeld *(D)

\section{KURK (16)}

'n Aanvaarbare benaming vir felleem.

Cork ${ }^{*}(\mathrm{E}) \quad \mathrm{Kurk}^{*}(\mathrm{~N})$ Kork ${ }^{*}(\mathrm{D})$

\section{KURKKAMBIUM Sien FELLOGEEN.}

LENTISEL (58)

Spesiale gedeelte van die periderm wat makroskopies waargeneem kan word as vratagtige struk ture wat dikwels lensvormig is. Dit bestaan uit ' $n$ los vulweefsel van selle wat min verkurk is. Die hooffunksie is die deurlaat van lug deur 'n andersins ondeurdringbare periderm.

Lenticel ${ }^{*}(E) \quad$ Lenticel *(N) Lentizelle *(D)

\section{LISIGEEN (60)}

'n Intersellulêre holte wat ontstaan het weens die disintegrasie van selle.

Lysigenous * $(\mathrm{E}) \quad$ Lysigeen * $(\mathrm{N}) \quad$ Lysigen *(D)

\section{LUMEN (59)}

Die selholte.

Lumen, (plural: lumina) ${ }^{*}(\mathrm{E})$ Lumen ${ }^{*}(\mathrm{~N}) \quad$ Lumen $*(D)$

\section{MARGO Sien STIPPELMEMBRAAN}

\section{MELKSAPBAAN (55)}

'n Term vir die spleetvormige, radiale openinge wat in gedroogde hout van sommige melksaphoudende boomsoorte soos dié van die Apocynaceae voorkom. Hierdie openinge word gekenmerk deur die aanwesigheid van melksapgange en het hulle oorsprong in die melksapbane van blare en okselknoppe. Opmerking: Foutiewe benamings is melksapkanale en melksapgange (sien MELKSAPGANG).

Latex trace *(E) Melksapbaan *(N) Milchröhrenspur *(D)

\section{MEI.KSAPSEL ( (57)}

'n Algemene benaming vir selle met 'n melksapinhoud. Opmerking: Hierdie enkele selle kan as 'n reeks 'n buisvormige struktuur vorm.

Laticifer *(E) Melksapcel*(N) Milchsaftzelle*(D)

\section{MELKSAPGANG (56)}

'n Melksapsel wat in 'n straal voorkom. Opmerking: Die gange is indiwiduele of reekse aangepaste selle maar nooit intersellulêre ruimtes nie.

Latex tube *(E) Melksapgang *(N) Milchröhre *(D)
MERISTEEM (61)

'n Weefsel wat tot aktiewe seldeling in staat is en waardeur nuwe selle tot die plantliggaam toevoeg word (sien KAMBIUM en MERISTEEM, APIKALE).

Meristem *(E) Meristeem *(N) Meristem *(D)

\section{MERISTEEM, APIKALE (62)}

Die groeipunt van 'n stingel of 'n wortel.

Meristem, apical *(E) Meristeem, groeipunt- *(N)

Meristem, Apikales *(D)

\section{MERISTEEM, GROEIPUNT- sien MERISTEEM, APIKALE}

\section{METAXILEEM (63)}

Dié gedeelte van die primêre xileem wat ná die protoxileem gevorm word wanneer lengtegroei nie meer plaasvind nie. Die trageale elemente van die metaxileem het stippels in die wande (sien PROTOXILEEM).

Metaxylem *(E) Metaxyleem *(N) Metaxylem*(D)

\section{MIDDELLAMELLA (51)}

Die gemeenskaplike selwandlaag tussen aangrensende selle wat hoofsaaklik uit pektiese stowwe bestaan. Opmerking: Die middellamella en die primêre selwand is nou verwant (sien MIDDELLAMELLA, SAAMGESTEL.DE) en spesiale tegnieke word vereis om tussen die twee lae te onderskei.

Intercellular layer ${ }^{*}(\mathrm{E})$ Intercellulaire laag ${ }^{*}(\mathrm{~N})$ Mittellamelle (Ursprüngliche) *(D)

\section{MIDDELLAMELLA, SAAMGESTELDE (54)}

'n Gerieflike term vir die saamgestelde laag wat uit die middellamella en die twee primêre selwande van aangrensende selle bestaan.

Lamella, compound middle *(E) Middenlamel, samegestelde ${ }^{*}(\mathrm{~N})$ Mittellamelle, Zusammengesetzte ${ }^{*}(\mathrm{D})$

MURG (121)

Die sentraalste gedeelte van die stingel of stam. Bestaan hoofsaaklik uit parenchiem of sagte weefsel.

$$
\text { Pith }^{*}(\mathrm{E}) \quad \text { Merg }^{*}(\mathrm{~N}) \quad \text { Mark }{ }^{*}(\mathrm{D})
$$

\section{MURGSTRAAL Sien STRAAL}

\section{MURGVLEK (122)}

in Onreëlmatige massa abnormale (meestal traumatiese) parenchimatiese weefsel wat in hout voorkom. Op lengtevlakke as strepe sigbaar. Dikwels veroorsaak deur insekte wat die vaatkambium beskadig het.

Pith fleck* ${ }^{*}(\mathrm{E}) \quad$ Mergulek *(N) Markfleck ${ }^{*}(\mathrm{D})$

\section{OLIESEL (65)}

in Gespesialiseerde sel met 'n olie-inhoud wat in die straal- of in die aksiale parenchiem voorkom. Gewoonlik rond. Opmerking: Beperk tot die houtagtige Angiospermae. Afgesien van die inhoud lyk dit net soos slymselle.

$$
\text { Oil cell }{ }^{*}(\mathrm{E}) \quad \text { Oliecel }{ }^{*}(\mathrm{~N}) \quad \text { Ölzelle *(D) }
$$




\section{PARENCHIEM (66)}

Weefsel wat saamgestel is uit baksteenvormige, gestrekte of isodiametriese selle met eenvoudige stippels. Ontstaan in hout uit (a) spoelvormige inisiaalselle deur dwarsdeling van die dogterselle (aksiale parenchiem) en (b) uit straalinisiaalselle (radiale of straalparenchiem) (sien PARENCHIEMVESEL, ONDERVERDEEL). Opmerking: Weefsel vir die berging en verspreiding van reserwe stowwe. Word hout- of xileemparenchiem genoem in die hout, en floëemparenchiem wanneer dit in die floëem voorkom.

Parenchyma ${ }^{*}\left(\right.$ E) Parenchym * $(N)$ Parenchym* ${ }^{*}(\mathrm{D})$

\section{PARENCHIEM, AANVANGS- (75)}

Apotrageale parenchiemvesels of -stringe aan die begin van die groeisone. Kan as enkele selle of as 'n band van variërende breedte, voorkom (sien PARENCHIEM, TERMINALE).

Parenchyma, initial *(E) Parenchym, initiaal * $(N)$

Parenchym, Initiales * $(D)$

\section{PARENCHIEM, ABAKSIAAL}

Unilaterale, paratrageale parenchiem aan die bas se kant van die houtvat.

Parenchyma, abaxial *(E) Parenchyma, abaxiaal

*(N) Parenchym, Abaxiales *(D)

\section{PARENCHIEM, ADAKSIAAL}

Unilaterale, paratrageale parenchiem aan die murg se kant van die houtvat.

Parenchyma, adaxial *(E) Parenchyma, adaxiaal *(N) Parenchym, Adaxiales *(D)

PARENCHIEM, AKSIALE (69)

Parenchiemselle wat ontstaan het uit spoelvormige inisiaalselle van die kambium (sien PARENCHIEM, STRAAL-).

Parenchyma, axial *(E) Parenchym, axiaal * $(N)$

Parenchym, Axiales *(D)

\section{PARENCHIEM, ALIFORM Sien PARENCHIEM,} VLERKVORMIGE

\section{PARENCHIEM, APOTRAGEALE (68)}

Aksiale parenchiem sonder direkte kontak met houtvate. Opmerking: Die term sluit terminale parenchiem, verspreide parenchiem en parenchiembande in.

Parenchyma, apotracheal ${ }^{*}(\mathrm{E})$ Parenchym, apotracheaal ${ }^{*}(\mathrm{~N})$ Parenchym, Apotracheales *(D)

\section{PARENCHIEM, bas- Sien PARENCHIEM, Flo- ËEM-}

\section{PARENCHIEM, DISJUNKTE (74)}

Aksiale en/of radiale parenchiem waarvan die selle tydens die differensiasieproses gedeeltelik van mekaar geskei word.

Parenchyma, disjunctive * ${ }^{*}(\mathrm{E})$ Parenchym, disjunct ${ }^{*}(\mathrm{~N})$ Parenchym, Disjunktes ${ }^{*}(\mathrm{D})$

\section{PARENCHIEM, FLOËEM (77)}

Aksiale parenchimatiese weefsel in die floëem. Sinoniem: Basparenchiem.

Parenchyma, phloem * ${ }^{*}$ E) Parenchym, floëem * $(N)$

Parenchym, Phloem- *(D)

\section{PARENCHIEMSEL, GESEPTEERDE (88)}

Aksiale of radiale parenchiemsel met een of meer dun dwarswande wat oor die sellumen strek. Opmerking: In hierdie elemente verdeel die protoplas nadat die sekondêre selwand gevorm is.

Parenchyma cell, septate *(E) Parenchymvezel, gedeelde ${ }^{*}(\mathrm{~N}) \quad$ Parenchymzelle, Gefächerte ${ }^{*}(\mathrm{D})$

\section{PARENCHIEM, INISIale Sien PARENCHIEM,} TERMINALE

\section{PARENCHIEM, KORT TANGENSIALE BANDE} (73)

Apotrageale parenchiemselle of parenchiemstringe wat in 'n dwarssnee, groepe in die vorm van kort, tangensiale bandjies tussen die strale vorm. Opmerking: Hierdie tipe parenchiem is dikwels ook onreëlmatig netvormig (sien PARENCHIEM, NETVORMIG).

Parenchyma, diffuse-in-aggregates * $(E)$ Parenchym, korte tangentiale bandjes ${ }^{*}(\mathrm{~N})$ Parenchym. Diffus aggregiertes *(D)

\section{PARENCHIEM, LEERVORMIGE (80)}

'n Term vir die leervormig gerangskikte parenchiem in 'n dwarssnee. Ontstaan deurdat strale en tangensiale bande aksiale parenchiem baie reëlmatig voorkom. Die parenchiembande het 'n hoër frekwensie per eenheidoppervlakte en is ook duidelik smaller as die strale (sien PARENCHIEM, NETVORMIG).

Parenchyma, scalariform *(E) Parenchym, laddervormig * $(\mathrm{N})$ Parenchym, Leiterförmiges *(D)

\section{PARENCHIEM, MARGINAAL Sien PAREN-} CHIEM, TERMINALE

\section{PARENCHIEM, NETVORMIGE (79)}

'n Term wat die rangskikking van ongeveer dieselfde wydte strale en tangensiale parenchiembande in ' $n$ dwarssnee, waar dit 'n reëlmatige, netvormige patroon vorm, beskryf (sien PARENCHIEM, LEERVORMIGE).

Parenchyma, reticulate *(E) Parenchym, netvor$\mathrm{mig}^{*}(\mathrm{~N})$ Parenchym, Netzförmiges ${ }^{*}(\mathrm{D})$

\section{PARENCHIEM, PARATRAGEALE (76)}

Aksiale parenchiem wat in kontak met houtvate voorkom. Opmerking: Hierdie term sluit yl paratrageale. vasisentriese, vleuelvormige en samevloeiende parenchiem in.

Parenchyma, paratracheal *(E) Parenchym, paratracheaal ${ }^{*}(N)$ Parenchym, Paratracheales ${ }^{*}(D)$

PARENCHIEM, RADIALE Sien PARENCHIEM, STRAAL- 
PARENCHIEM, SAMEVLOEIENDE (71)

Paratrageale, aksiale parenchiem wat in dwarssneë as onreëlmatige, tangensiale of diagonale bande sigbaar is.

Parenchyma, confluent ${ }^{*}(\mathrm{E})$ Parenchym, confluent * $(\mathrm{N})$ Parenchym, Confluentes *(D)

\section{PARENCHIEMSEL, SPOELVORMIGE (87)}

'n Aksiale parenchiemsel wat uit 'n spoelvormige inisiaalsel ontwikkel het en waarin daar geen dwarswande gevorm is nie.

Parenchyma cell, fusiform ${ }^{*}(\mathrm{E})$ Parenchymvezel, ongedeelde ${ }^{*}(\mathbf{N})$ Parenchymzelle, Spindelförmige *(D)

PARENCHIEM, STRAAL- (78)

Parenchiem waaruit vaatstrale gedeeltelik of geheel saamgestel is.

Parenchyma, ray ${ }^{*}(\mathrm{E})$ Parenchym, straal- * $(\mathrm{N})$ Parenchym, Markstrahl- *(D)

\section{PARENCHIEM, TERMINALE (82)}

Apotrageale aksiale parenchiemselle wat of enkel of in min of meer aaneenlopende bande van wisselende breedte aan die einde van 'n seisoen se groei voorkom. Opmerking: Voordat daar tussen "terminale" en "inisiale" parenchiem onderskei is, is hierdie term vir beide vorme gebruik en dit word soms nog steeds só gebruik.

Parenchyma, terminal * $(E)$ Parenchym, terminaal ${ }^{*}(\mathrm{~N}) \quad$ Parenchym, Terminales ${ }^{*}(\mathrm{D})$

\section{PARENCHIEM, TRAUMATIESE (83)}

Parenchiemselle van onreëlmatige grootte, vorm en rangskikking, waarvan die ontstaan na die beskadiging van die kambium teruggevoer kan word. Sinoniem: wondparenchiem.

Parenchyma, traumatic * $(E)$ Parenchym, traumatisch ${ }^{*}(\mathrm{~N}) \quad$ Parenchym, Wund- *(D)

\section{PARENCHIEM, UNILATERAAL PARATRAGEA-}

\section{LE (84)}

Paratrageale, aksiale parenchiem wat nie volledig rondom die houtvat voorkom nie. Opmerking: Hierdie parenchiem kan verder verdeel word as eensydig yl, eensydig vleuelvormig en eensydig samevloeiend (sien PARENCHIEM, Yl. PARATRAGEALE).

Parenchyma, unilaterally paratracheal ${ }^{*}(E)$ Parenchym, unilateraal paratracheaal ${ }^{*}(\mathbf{N}) \mathrm{Pa}-$ renchym, Einseitig paratracheales ${ }^{*}(D)$

\section{PARENCHIEM, VASISENTRIESE (85)}

Paratrageale aksiale parenchiem wat in dwarssneë 'n volledige mantel van verskillende breedtes rondom die houtvat vorm. Dit kan rond tot ovaalvormig wees.

Parenchyma, vasicentric * $(E)$ Parenchym, vasicentrisch *(N) Parenchym, Vasizentrisches *(D)

\section{PARENCHIEM, VATSTANDIGE Sien PAREN- CHIEM, PARATRAGEAI.E}

PARENCHIEM, VERSPREII) (72)

Enkele apotrageale parenchiemstringe of enkele selle wat in 'n dwarssnee onreëlmatig verspreid tussen die vesels voorkom.

Parenchyma, diffuse ${ }^{*}(E)$ Parenchym, diffuus

${ }^{*}(\mathrm{~N})$ Parenchym, Diffuses *(D)

\section{PARENCHIEM, VERTIKALE Sien PAREN- CHIEM, AKSIALE}

\section{PARENCHIEM, VLERKVORMIGE (67)}

Paratrageale, aksiale parenchiem wat in 'n dwarssnee vlerkvormige uitbreidings in die tangensiale rigting toon.

Parenchyma, aliform * ${ }^{*}(E)$ Parenchym, aliform

*(N) Parenchym, Flügelförmiges *(D)

\section{PARENCHIEM, VUL-Sien VERBINDINGSWEEF-} SEL

PARENCHIEM, VUL- Sien FLOËEM, INGESLOTE

\section{PARENCHIEM, WOND- Sien PARENCHIEM, TRAUMATIESE}

\section{PARENCHIEM, XILEEM-, (86)}

Parenchiem van die xileem, gewoonlik in twee vorme (1) aksiaal en (2) radiaal (straalparenchiem). Sinoniem: houtparenchiem.

Parenchyma, xylem *(E) Parenchym, xyleem*(N) Parenchym, Xylem- *(D)

\section{PARENCHIEM, YL PARATRAGEALE (81)}

'n Onvolledige mantel van paratracheale, aksiale parenchiem rondom houtvate, of slegs enkele, parenchiemselle wat rondom die houtvat voorkom (sien PARENCHIEM, UNILATERAAL PARATRAGEALE).

Parenchyma, scanty paratracheal *(E) Parenchym, spaarzaam paratracheaal ${ }^{*}(\mathrm{~N}) \quad$ Parenchym, Spärlich paratracheales * $(D)$

\section{PARENCHIEMBANDE (70)}

Aksiale parenchiem wat in ' $n$ dwarssnee konsentriese bande vorm. Opmerking: Bekend as apotrageale parenchiem wanneer dit losstaande van die houtvate voorkom en paratrageale parenchiem wanneer dit in aanraking met die houtvate is (Sien PARENCHIEM, SAMEVLOEIEND).

Parenchyma, banded *(E) Parenchymbanden *(N) Parenchym, Gebändertes *(D)

\section{PARENCHIEMSTRING (89)}

in Aksiale reeks van twee of meer parenchiemselle wat uit 'n enkele, spoelvormige inisiaal ontwikkel het.

Parenchyma strand ${ }^{*}(E)$ Parenchymstreng ${ }^{*}(N)$

Parenchymstrang *(D)

\section{PERFORASIE, ENKELVOLDIGE (91)}

in Enkele, gewoonlik groot en min of meer ronde opening in die perforasieplaat (die kontakvlak tussen houtvatelemente) Sien PERFORASIE, VEELVOUDIGE).

Perforation, simple * $(E)$ Doorboring, enkelvoudige $^{*}(\mathrm{~N})$ Durchbrechung. Einfache ${ }^{*}(\mathrm{D})$ 


\section{PERFORASIE, HOUTVAT- (92)}

'n Opening vanaf een houtvatelement na 'n volgende houtvatelement, hoofsaaklik in die eindwande van houtvatelemente.

Perforation, vessel $*(\mathrm{E})$ Doorboring, vat- ${ }^{*}(\mathrm{~N})$ Durchbrechung, Gefäss- ${ }^{*}(\mathrm{D})$

\section{PERFORASIE, SAAMGESTELDE (90)}

Die geperforeerde eindwand van 'n houtvatelement met twee of meer perforasies.

Perforation, multiple ${ }^{*}(E) \quad$ Doorboring, veelvoudige ${ }^{*}(\mathrm{~N})$ Durchbrechung, Vielfache ${ }^{*}(\mathrm{D})$

\section{PERFORASIEPLAAT (93)}

'n Term vir dié area van die houtvatelement se eindwand wat oorspronklik nie geperforeer was nie, maar wat later die geperforeerde kontakarea tussen twee houtvatelemente uitmaak.

Perforation plate ${ }^{*}(\mathrm{E})$ Tussenschot ${ }^{*}(\mathrm{~N})$ Perforationsplatte $*(\mathrm{D})$

\section{PERFORASIEPLAAT, EPHEDROÏEDE (94)}

' $n$ Tipe veelvoudige perforasieplaat van 'n houtvatelement met klein ronde perforasies in die eindwand (Soos in Ephedra).

Perforation plate, ephedroid *(E) Tussenschot met ephedroide doorboring ${ }^{*}(\mathrm{~N})$ Perforationsplatte, Ephedroide *(D)

\section{PERFORASIEPLAAT, LEERVORMIGE (96)}

'n Tipe saamgestelde perforasieplaat van 'n houtvatelement met 'n aantal lang en smal perforasies in die eindwand wat min of meer parallel voorkom. Die oorblyfsels van die selwand wat tussen die perforasies voorkom kan met die sporte van 'n leer vergelyk word.

Perforation plate, scalariform ${ }^{*}(\mathrm{E})$ Tussenschot met laddervormige doorboring $*(\mathrm{~N})$ Perforationsplatte, Leiterförmige *(D)

\section{PERFORASIEPLAAT, NETVORMIGE (95)}

'n Tipe saamgestelde perforasieplaat van 'n houtvatelement met ' $n$ aantal ronde perforasies in die eindwand wat só gerangskik is dat dit 'n netvormige voorkoms het.

Perforation plate, reticulate ${ }^{*}(E)$ Tussenschot met netvormige doorboring ${ }^{*}(\mathrm{~N})$ Perforationsplatte, Netzförmige *(D)

\section{PERFORASIERAND (97)}

Oorblyfsels van ' $n$ perforasieplaat. Die rand van ' $n$ eenvoudige perforasieplaat.

Perforation rim * $(\mathrm{E})$ Perforasierand ${ }^{*}(\mathrm{~N})$ Perforationsrand oder-leiste *(D)

\section{PERIDERM (98)}

Die sellae wat in ouer stamme en wortels die epidermis as 'n ondeurlaatbare omhulsel vervang. Sluit die felleem, fellogeen en felloderm in.

Periderm * ${ }^{*}(\mathrm{E}) \quad$ Periderm $*(N) \quad$ Periderm *(D)

PORE (132)

'n Tegniese term vir houtvate en trageïede soos gesien in dwarssneë. Sinoniem: Houtvat.

Pore ${ }^{*}(\mathrm{E}) \quad$ Porie ${ }^{*}(\mathrm{~N}) \quad$ Pore ${ }^{*}(\mathrm{D})$

\section{PROKAMBIUM}

Primêre meristematiese weefsel wat deur die apikale meristeem gevorm word en waaruit die primêre vaatweefsel differensieer.

$$
\text { Procambium }{ }^{*}(\mathrm{E}) \text { Procambium }{ }^{*}(\mathrm{~N}) \text { Prokam- }
$$$$
\text { bium *(D) }
$$

\section{PROSENCHIEM (136)}

'n Algemene term vir verlengde selle met geslote, spits punte. Opmerking: 'n Term voorheen gebruik as 'n versamelnaam vir vesels, trageïede en soms houtvatelemente, maar wat parenchiem spesifiek uitsluit.

Prosenchyma $*(\mathrm{E})$ Prosenchym ${ }^{*}(\mathrm{~N})$ Prosenchym *(D)

\section{PROTOPLAS (137)}

Die seiinhoud sonder die vakuool, wat deur die selwand ingesluit word. Opmerking: Protoplas $=$ Protoplasma en vakuool.

Protoplast * $(\mathrm{E})$ Protoplast ${ }^{*}(\mathrm{~N})$ Protoplast ${ }^{*}(\mathrm{D})$

\section{PROTOXILEEM (138)}

Die eerste gevormde primêre xileem met trageale elemente wat kenmerkend ring- of spiraalverdikkings besit (sien METAXILEEM).

Protoxylem *(E) Protoxyleem * ${ }^{*}(\mathrm{~N})$ Protoxylem *(D)

\section{RHYTIDOOM (154)}

'n Tegniese term vir die buitenste gedeelte van die bas wat bestaan uit periderm en ander weefsels (korteks en floëem). Hierdie ander weefsels word deur die vorming van die periderm geïsoleer. Opmerking: Wanneer die rhytidoom tot niet gaan, het die plant 'n gladde stam. Wanneer dit behoue bly, word 'n stam met 'n dik, veselagtige, gegroefde of kurkagtige oppervlaklaag gevorm.

Rhytidome * ${ }^{*}$ E) Rhytidoma * $(N)$ Rhytidom *(D)

\section{RIFFELMERKE Sien GESTRATIFISEERDE ELE-} MENTE.

SEL (11)

' $n$ Wandomringde holte waarin daar steeds protoplas$\mathrm{ma}$ is of minstens in die jeugstadium was. Selle is die basiese boustene van plantaardige weefsels.

Cell ${ }^{*}(\mathrm{E}) \quad \mathrm{Cel}{ }^{*}(\mathrm{~N}) \quad$ Zelle ${ }^{*}(\mathrm{D})$

\section{SELWAND (12)}

'n Gestruktureerde laag van hoofsataklik sellulose en pektiese stowwe wat later met lignien of suberien, afkomstig van die protoplasma, geïmpregneer word. In die selwand kom verskillende stippeltipes voor (sien STIPPEL). In volwasse selle kan die volgende onderskei word: (1) Middellamella: 'n gemeenskaplike laag tussen aangrensende selle. (2) Primêre wand: die wand van die meristematiese sel wat gedurende die differensiasie van die sel veranderinge ondergaan het. (3) Sekondêre wand: die wandlae wat aan die binnekant van die primêre selwand neergelê word. (4) Tersiêre wand: die binneste laag van die selwand wat aan die sellumen grens. Dikwels met vratte bedek.

Cell wall ${ }^{*}(\mathrm{E})$ Celwand ${ }^{*}(\mathrm{~N})$ Zellwand ${ }^{*}(\mathrm{D})$ 
SELWANDSPLEET (13)

'n Skeurtjie in die sekondêre selwand, bv. in drukhouttrageiede.

Cell wall check ${ }^{*}(\mathrm{E})$ Celwand, spleet in ${ }^{*}(\mathrm{~N})$ Zellwandriss *(D)

\section{SIFPLAAT (171)}

Die eindwand van ' $n$ sifvatelement met 'n enkele sifveld (enkelvoudige sifplaat), of verskeie sifvelde wat of leervormig of netvormig gerangskik is (saamgestelde sifplaat).

Sieve plate ${ }^{*}(\mathrm{E}) \quad$ Zeefplaat $*(N) \quad$ Siebplatte *(D)

\section{SIFSEL (170)}

'n Floëemsel met relatief ongedifferensieerde sifvelde wat in al die selwande voorkom. Sifplate op die eindwande ontbreek. Die belangrikste funksie van die floëemsel in die Gymnospermae is die vervoer van organiese voedingstowwe.

Sieve cell ${ }^{*}(\mathrm{E}) \quad$ Zeefcel $*(\mathrm{~N}) \quad$ Siebzelle $*(\mathrm{D})$

\section{SIFSONE Sien SIFVELD}

\section{SIFVAT (172)}

'n Buis bestaande uit ' $n$ aksiale reeks sifvatelemente vir die vervoer van organiese voedingstowwe.

Sieve tube ${ }^{*}(\mathrm{E}) \quad$ Zeefvat ${ }^{*}(\mathrm{~N})$ Siebröhre ${ }^{*}(\mathrm{D})$

\section{SIFVATELEMENT (173)}

'n Enkele sel van 'n sifvat. Gemeenskaplike skuins- of horisontale dwarswande bestaan uit sifplate. Soms kom minder gespesialiseerde sifvelde op die selwande voor.

Sieve tube member ${ }^{*}(\mathrm{E})$ Zeefvatlid ${ }^{*}(\mathrm{~N})$ Siebröhrenglied *(D)

\section{SIFVELD (169)}

'n Area in die selwand van 'n sifvat of sifsel waarin klein porieë voorkom waardeur die protoplasma van aangrensende floëemselle met mekaar in kontak is.

Sieve area ${ }^{*}(\mathrm{E}) \quad$ Zeefveld ${ }^{*}(\mathrm{~N}) \quad$ Siebfeld ${ }^{*}(\mathrm{D})$

\section{SKEDESELLE (168)}

'n Enkele of 'n reeks langgestrekte selle wat soos 'n skede op die buiterand van veelryige strale, soos gesien in tangensiale sneë, voorkom (Sien STRAALSEL, REGOPSTAANDE).

Sheath cell ${ }^{*}(\mathrm{E}) \quad$ Omhullende cel ${ }^{*}(\mathrm{~N}) \quad$ Scheidenzellen $*(\mathrm{D})$

\section{SKISOLISIGEEN (166)}

Aanvanklik het die lugruimte ontstaan deur die splitsing van die middellamella, waarna die gevormde ruimte in die weefsel deur die disintergrasie van omringende selle wyer word.

Schizo-lysigenous *(E) Schizolysigeen ${ }^{*}(\mathrm{~N})$

Schizo-lysigen *(D)

\section{SKISOCEEN (165)}

'n Intersellulêre ruimte wat ontstaan deur die splitsing van dic middellamella. Opmerking: Selle raak los van mekaar weens dic opbreking van die gemeenskaplike gedeelte (middellamela) tussen die twee aangrensende selle.

Schizogenous ${ }^{*}(\mathrm{E}) \quad$ Schizogeen ${ }^{*}(\mathrm{~N}) \quad$ Schizogen *(D)

\section{SKLEREÏEDE (167)}

Selle met hoofsaaklik 'n meganiese steunfunksie wat uit 'n parenchiemsel ontwikkel en wat nie duidelik prosenchimaties is nie. Dit het dik, dikwels gelignifiseerde sekondêre wande waarin baie vertakte stippelkanale is. Die volgroeide sel is meestal sonder protoplasma. Sinoniem: sklerenchiemsel. Opmerking: Sklereïede se vorm varieer van polihedraal tot langwerpig (sklerenchiemvesels). Die selle is dikwels vertak. Besonder sterk verdikte en vertakte sklereiede kom dikwels in die bas. maar selde in die hout voor. Bragisklereïede (steenselle) wat min of meer isodiametries is, word dikwels in die hout aangetref. Sklereïede met relatiewe dun wande word soms in die straalweefsel gevorm.

Sclereid *(E) Sklereïde *(N) Sklereide *(D)

\section{SKLERENCHIEMSEL Sien SKLEREÏEDE}

\section{SKLEROTIESE SEL Sien SKLEREÏEDE}

\section{SKROEFVERDIKKINGS Sien SPIRAALVERDIK- KINGS}

\section{SLUITVLIES Sien STIPPELMEMBRAAN}

\section{SLYMSEL (64)}

'n Gespesialiseerde sel (idioblast) wat in radiale of aksiale parenchiem voorkom. Die selinhoud bestaan uit 'n koolwaterstofkompleks wat maklik water opneem en 'n slymagtige stof vorm. Die selle is gewoonlik rond en dunwandig. Opmerking: Die selle is beperk tot die houtagtige Dicotyledoneae en afgesien van inhoud. lyk dit net soos olieselle.

Mucilage cell *(E) Slijmcel *(N) Schleimzelle *(D)

\section{SPINTHOUT (163)}

Die buitenste gedeelte van die boom se hout wat nog lewend is en waarin daar nog lewende selle met reserwestowwe soos byvoorbeeld setmeel, in voorkom. Gewoonlik ligter van kleur, met 'n laer digtheid as kernhout (Sien KERNHOUT). Sinoniem: Alburnum.

Sapwood *(E) Spint *(N) Splintholz *(D)

\section{SPINTHOUT, INGESLOTE (164)}

In die kernhout is soms ingeslote hout wat nog steeds die voorkoms en eienskappe van spinthout het. Hierdie selle is nie meer lewend soos in normale spinthout nie, maar reserwestowwe is nog teenwoordig.

Sapwood, included ${ }^{*}(\mathrm{E})$ Spint, ingesloten ${ }^{*}(\mathrm{~N})$ Splintholz, Eingeschlossenes *(D)

\section{SPIRAALVERDIKKINGS (174)}

Spiraalvormige verdikkings aan die binnekant van die sekondère selwand by houtvate. trageiede en vesels van die sekondêre xileem.

Spiral thickening ${ }^{*}(E)$ Spiraalverdikking ${ }^{*}(N)$

Schraubenverdickung *(D) 


\section{SPOELVORMIGE INISIAAL (41)}

'n Kambiuminisiaalsel wat in 'n tangensiale snee spoelvormig vertoon en wat oorsprong gee aan aksiale xileem- of floëemelemente.

Fusiform initial ${ }^{*}(\mathrm{E})$ Fusiforme initiaal ${ }^{*}(\mathrm{~N})$

Fusiforminitiale *(D)

\section{STEENSEL (175)}

'n Ongeveer isodiametriese sel met dik, sterk gelignifiseerde sekondêre wande wat uit 'n hele aantal lae bestaan en waarin vertakte stippelkanale kan voorkom (sien SKLEREÏEDE). Sinoniem: Bragisklereïede.

Stone cell *(E) Steencel *(N) Steinzelle *(D)

\section{STIPPEL (108)}

'n Dun gedeelte van die selwand waar die sekondêre selwandlae ontbreek en die middellamella en primêre selwand die stippelmembraan vorm. Dit is 'n verbinding tussen aangrensende selle. Verskillende tipes stippels soos eenvoudige, hof- en tregterstippels word onderskei. Stippeltipes:

Eenvoudige stippel: $\quad$ 'n Stippel waarvan die stippelkanaal oor die volle lengte ewe wyd is.

Hofstippel:

Blinde stippel:

Beklede stippel:

Cupressoïede stippel: 'n Stippel van die kruisingsveld tussen trageiede en straalparenchiemselle in die vroeë hout van die Gymnospermae waar die stippelopening spleetvormig. smal en nou is, nouer as die breedte van die spasie tussen die spleet en die stippelrand, o.a. in Cupressus.

Piceoïede stippel: $\quad$ 'n Stippel in die kruisingsveld tussen trageiede en straalparenchiem, in die vroeë hout van die Gymnospermae waar die spleetagtige stippelopening smal is en daar byna niks van die spleet verby die stippel se hof strek nie. Die spleet is nouer as die breedte van die spasie tussen die spleet en die stippelrand, soos in Picea.

Pinoïede stippel: $\quad$ 'n Term waarmee die kleinste stippels beskryf word, soos wat dit aangetref word in die kruisingsveld tussen trageiede en straalparenchiemselle in die vroeë hout van verskillende Pinus-spesies (uitgesonderd die groot venstervormige stippels van Pinus sylvestris en $P$. stohus). Hierdie stippels is of gewoon of het 'n groot nou hof van verskillende vorme en afmetings.

Taksioïede stippel: $\quad$ 'n Stippel in die kruisingsveld tussen trageïede en straalparenchiemselle in die vroeë hout van naaldhout waar die stippelopening eiervormig tot rond is en groter is as die breedte van die spasie tussen die stippelopening en die stippelrand, soos in Sequoia.

Venstervormige stippel: Groot, gewone stippels in die kruisingsveld van trageïede en straalparenchiemselle in die vroeë hout van sommige Pinus-spesies. $(P$. sylvestris en $P$. cembra). Hierdie stippel kan tot die hele kruisingsveld beslaan (sien PINOÏEDE STIPPEL).

Pit $*$ (E) Stippel *(N) Tüpfel *(D)

STIPPEL, PRIMORDIALE Sien STIPPELVELD, PRIMERE

STIPPELLOLTE (112)

Die volle ruimte van 'n stippel, vanaf die stippelmembraan tot die lumen van die sel. Groot by hofstippels.

Pit cavity ${ }^{*}(\mathrm{E})$ Stippelholte ${ }^{*}(\mathrm{~N})$ Tüpfelhöhle *(D)

STIPPELING (123)

' $n$ Term om die wyse waarop stippels of stippelpare gerangskik is, aan te dui.

Pitting *(E) Stippeling * $(\mathrm{N}) \quad$ Tüpfelung *(D)

\section{STIPPELING, AFWISSELENI)E (124)}

Veelryige stippeling waar die stippels in diagonale rye lê. Opmerking: Wanneer stippels teenaan mekaar gelë̈ is, kry die stippels ' $n$ seshoekige voorkoms.

Pitting, alternate * $(E) \quad$ Stippeling, afwisselende (alternierende) ${ }^{*}(\mathrm{~N})$ Tüpfelung, Wechselständige (alternierende) ${ }^{*}(\mathrm{D})$

STIPPELING, EENSYDIG SAAMGESTELDE (131)

Stippeling waar een stippel in 'n sel by twee of meer kleiner stippels in aangrensende selle aansluit. 
Pitting, unilaterally compounded ${ }^{*}(E)$ Stippeling, eenzijdig samengestelde *(N) Tüpfelung, Einseitig zusammengesetzte ${ }^{*}(\mathrm{D})$

\section{STIPPELING, INTERVAAT (126)}

'n Term wat in 'n breër sin gebruik word vir stippeling tussen trageale elemente en in 'n houtanatomiese sin vir die stippeling tussen houtvatelemente.

Pitting, intervascular ${ }^{*}(E)$ Stippeling, intervasculaire ${ }^{*}(\mathrm{~N}) \quad$ Tüpfelung, Intervaskulare ${ }^{*}(\mathrm{D})$

\section{STIPPELING, KRUISINGSVELD- (125)}

Die stippeling wat voorkom in die selwande van straalparenchiem en aksiale trageiede waar hierdie twee elemente kruis soos gesien in radiale sneë. Opmerking: 'n Term wat hoofsaaklik vir Gymnospermae-hout gebruik word.

Pitting, cross-field *(E) Stippeling, kruisingsveld${ }^{*}(\mathrm{~N})$ Tüpfelung, Kreuzungsfeld- *(D)

\section{STIPPELING, LEERVORMIGE (129)}

Stippeling waar lang en smal of lynvormige hofstippels soos sporte van 'n leer gerangskik is.

Pitting, scalariform *(E) Stippeling, laddervormige *(N) Tüpfelung, Leiterförmige *(D)

\section{STIPPEL, PRIMORDIALE. Sien STIPPELVELD, PRIMÊRE}

STIPPELING, SIF- (130)

'n Rangskikking van klein stippels in sifvormige groepe.

Pitting, sieve ${ }^{*}(\mathrm{E})$ Stippeling, zeef- ${ }^{*}(\mathrm{~N})$ Tüpfelung, Sieb- ${ }^{*}(\mathrm{D})$

\section{STIPPELING, STRAAL-HOUTVAT (128)}

Die stippeling tussen 'n straalsel en 'n hout vatelement. Opmerking: Die volgende tipes kan onderskei word: spleetvormig-horisontaal, spleetvormig-vertikaal, niervormig, groot, gerond en soos intervaatstippeling.

Pitting, ray-vessel ${ }^{*}(\mathrm{E})$ Stippeling, straal-vat ${ }^{*}(\mathbf{N})$

Tüpfelung, Markstrahl-Gefäss- *(D)

\section{STIPPELING, TEENOORSTAANDE (127)}

'n Veelryige stippeling waar die stippels in horisontale pare of in kort, horisontale rye voorkom. Opmerking: Indien die stippels teenaan mekaar voorkom, lyk die gewoonlik ronde stippelomtrek reghoekig.

Pitting, opposite ${ }^{*}(E)$ Stippeling, tegenoverstaan$\mathrm{de}^{*}(\mathrm{~N})$ Tüpfelung. Gegenüberstehende (opponierte) ${ }^{*}(\mathrm{D})$

\section{STIPPEI.KAMER (113)}

Die ruimte tussen die stippelmembraan en die stippelrand.

Pit chamber ${ }^{*}(\mathrm{E})$ Stippelkamer ${ }^{*}(\mathrm{~N})$ Tüpfelkammer $\left.{ }^{*}(\mathrm{I})\right)$

\section{STIPPELKANAAI, (111)}

Die kanaal wat strek vanaf die sellumen tot die stippelmembraan.

Pit canal ${ }^{*}(\mathrm{E})$ Stippelkanaal ${ }^{*}(\mathrm{~N})$ Tüpfelkanal *(D)
STIPPELKRAAG (110)

Die oorhangende gedeelte van die sekondêre wand by 'n hofstippel (sien STIPPELPAAR, HOF-)

Pit border *(E) Stippeirand *(N) Tüpfelwulst *(D)

\section{STIPPELMEMBRAAN (114)}

Dié gedeelte van die middellamella en die twee primêre selwande tussen 'n stippelpaar. By die Gymnospermae se hofstippels is die sentrale gedeelte meestal verdik. Hierdie verdikte, ondeurlaatbare gedeelte is die torus en die dun onverdikte gedeelte wat die torus omring, die margo.

Pit membrane *(E) Stippelmembraan *(N) Tüpfelschliesshaut ${ }^{*}(\mathrm{D})$

\section{STIPPELOPENING (109)}

Die opening of mond van 'n stippel aan die sellumenkant van die stippelkanaal. Die volgende terme beskryf die verskillende stippelopeninge by hofstippels: Binne-opening: Die opening van die hofstippelkanaal in die sellumen.

Buite-opening: Die opening van die hofstippelkanaal in die stippelholte.

Ingeslote: Wanneer die omtrek van die binneopening van buite gesien, kleiner en ingeslote is binne die totale stippelrand.

lensvormig: Die opening lyk soos die deursnee van 'n dubbele konveks lens.

Samevloeiend: Spleetvormige openinge wat bymekaar aansluit en gesamentlik groewe aan die binnekant van die sekondêre wand vorm.

Uitstrekkend: Wanneer die omtrek van die binneopening. van buite gesien, groter is as die totale stippelwand.

Pit aperture ${ }^{*}(\mathrm{E})$ Stippelspleet ${ }^{*}(\mathrm{~N}) \quad$ Tüpfelöffnung (Apertur) *(D)

\section{STIPPELPAAR (116)}

Twee komplimenterende stippels van aangrensende selle.

Pit-pair ${ }^{*}\left(\right.$ E) $\quad$ Stippelpaar ${ }^{*}(\mathrm{~N}) \quad$ Tüpfelpaar ${ }^{*}(\mathrm{D})$

STIPPELPAAR, ENKELVOUDIG Sien STIPPELPAAR, EENVOUDIGE

\section{STIPPELPAAR, EENVOUDIGE (120)}

'n Eenvoudige stippelpaar tussen aangrensende selle. Pit-pair, simple ${ }^{*}(\mathrm{E})$ Stippelpaar, gewoon ${ }^{*}(\mathrm{~N})$ Tüpfelpaar, Einfaches ${ }^{*}(\mathrm{D})$

\section{STIPPELPAAR, HALWE HOF- (119)}

'n Stippelpaar tussen twee aangrensende selle wat uit in eenvoudige en ' $n$ hofstippel bestaan.

Pit-pair, halfbordered ${ }^{*}(\mathrm{E})$ Stippelpaar met eenzijdige hof *(N) Tüpfelpaar, Einseitig behöftes *(D)

\section{STIPPELPAAR, GESLOTE (117)}

Hofstippelpaar in gelignifiseerde selwande waarin die stippelmembraan soveel sywaarts verplaas is dat een van die stippelopeninge gesluit word. ' $n$ Term hoof- 
saaklik van toepassing op die hout van die Gymnospermae.

Pit-pair, aspirated *(E) Stippelpaar, gesloten *(N) Tüpfelpaar, Verschlossenes *(D)

\section{STIPPELPAAR, HOF- (118)}

'n Hofstippelpaar tussen twee aangrensende selle se gelignifiseerde selwande, waar die stippelmembraan oorkoepel word deur 'n sekondêre selwand.

Pit-pair, bordered *(E) Stippelpaar, hof- ${ }^{*}(\mathrm{~N})$ Tüpfelpaar, Behöftes *(D)

\section{STIPPELVELD, PRIMÊRE (115)}

'n Dunner gedeelte van die middellamella en die primêre selwande waardeur daar plasmodesmas verloop en waarin daar gewoonlik een of meer stippelpare sal ontwikkel. Sinoniem: Primordiale stippel.

Pit-field, primary ${ }^{*}(\mathrm{E})$ Stippelveld, primair ${ }^{*}(\mathrm{~N})$ Tüpfelfeld, Primäres *(D)

\section{STRAAL (139)}

'n Samestelling van selle wat radiaal in die xileem en floëem verloop en wat respektiewelik xileem- en floëemstrale genoem word. Opmerking: Die term murgstraal word tans beperk tot die parenchiem wat die korteks met die murg verbind. Die volgende terme beskryf die strale:

Straal, heterosellulêr 'n Straal wat uit verskillende tipes selle bestaan. bv. neerliggende en regopstaande en of vierkantige selle. Opmerking: By die Gymnospermae bestaan die xileemstrale dikwels uit parenchiemselle en straaltrageiede.

Straal, homosellulêr 'n Straal wat uit een tipe sel bestaan, byvoorbeeld slegs neerliggende of regopstaande of vierkantige selle. Opmerking: By die hout van die Angiospermae is die straal uitsluitlik uit parenchiemselle opgebou.

Straalweefsel, heterogeen Straalweefsel waarvan die afsonderlike strale geheel of gedeeltelik uit meer as een tipe sel bestaan.

Straalweefsel, homogeen Straalweefsel waarvan die afsonderlike strale slegs uit neerliggende selle opgebou is. Opmerking: Nie van toepassing op die hout van Gymnospermae nie.

Ray*(E) Straal *(N) Markstrahl*(D)

STRAAL, FLOËEM- (143)

Die gedeelte van die straal wat deur die floëem verloop.

Ray, phloem *(E) Straal, floëem- *(N) Markstrahl. Phloem- *(D)
STRAAL, LENSVORMIGE Sien STRAAL, SPOELVORMIGE

STRAAL, MUITISERIALE (142)

'n Straal wat twee of meer selle breed is. Dit is die betroubaarste om die breedte van strale in tangensiale sneë te bepaal.

Ray, multiseriate ${ }^{*}(\mathrm{E})$ Straal, meerrijige $*(N)$

Markstrahl, Vielreihiger ${ }^{*}(\mathrm{D})$

\section{STRAAI, PRIMÊRE (144)}

'n Straal wat die korteks en murg verbind. By kruidagtige stingels is dit die weefsel tussen aangrensende vaatbundels.

Ray, primary ${ }^{*}(\mathrm{E})$ Straal, primair ${ }^{*}(\mathrm{~N})$ Markstrahl, Primärer *(I)

STRAAI, SAAMGESTELDE (140)

'n Groep klein, smal strale wat tussen enkele aksiale elemente (nie houtvate nie) voorkom en wat nie in dwarssneë met die blote oog of met lae vergroting die indruk van 'n enkele, breë straal skep nie.

Ray, aggregate ${ }^{*}(E)$ Straalaggregaat (schijnstraal)

${ }^{*}(\mathrm{~N})$ Markstrahl, Zusammengesetzter ${ }^{*}(\mathrm{D})$

\section{STRAAL, SEKONDÊRE (145)}

'n Straal wat deur die vaatkambium tydens die ontwikkeling van die sekondêre xileem gevorm word, en wat nie tot by die murg strek nie.

Ray, secondary *(E) Straal, secundaire *(N) Markstrahl, Sekundärer *(D)

\section{STRAAI, SPOELVORMIGE (141)}

'n Straal wat in tangensiale sneë lens- of spoelvormig vertoon. Die term beskryf gewoonlik strale in hout van die Gymnospermae waarin harskanale voorkom.

Ray, fusiform *(E) Straal, spoelvormige ${ }^{*}(\mathbf{N})$ Markstrahl, Spindelförmiger *(D)

STRAAI, UNISERIALE (146)

'n Straal wat slegs een sel breed is. Dit is die betroubaarste om straalbreedte in tangensiale sneë te bepaal. Ray, uniseriate *(E) Straal, eenrijige* $* N)$ Markstrahl, Einreihiger *(D)

STRAAI, XILEEM- (147)

Daardie gedeelte van 'n straal wat deur die xileem strek ( $\operatorname{sien}$ STRAAL, FIO ÖEM).

Ray, wood or xylem *(E) Straal, hout of xyleem*(N) Markstrahl, Holz- oder Xylem- *(D)

\section{STRAAI.INISIAAL. (15I)}

'n Kambiumsel waaruit die straalsel ontwikkel. Kom gewoonlik in groepe voor en is dikwels min of meer isodiametries.

Ray initial *(E) Straalinitial *(N) Markstrahlinitiale *(D)

\section{STRAALMERISTEEM SiEn STRAAIIVISIAAL.}

\section{STRAAISEL, NEERII(;GENI)E (148)}

'n Straalsel met die langste as in "n radiale rigting. Ray cell, procumbent *(E) Straalcel, liggende *(N) Markstrahlzelle, Liegende *(I)) 
STRAALSEL, REGOPSTAANDE (150)

'n Straalsel met die langste as in 'n aksiale rigting. Opmerking: Uniseriale strale, uniseriale straaldele en veral die punte van veelryige strale bestaan dikwels uit hierdie selle.

Ray cell, upright ${ }^{*}(\mathrm{E})$ Straalcel, staande ${ }^{*}(\mathrm{~N})$ Markstrahlzelle, Aufrechte *(D)

\section{STRAALSEL, VIERKANT1G (149)}

'n Straalsel wat in radiale sneë ongeveer isodiametries is. Opmerking: Uniseriale strale, uniseriale dele van strale en veral die punte van veelryige strale is soms uit hierdie selle opgebou. Vierkantige en regopstaande straalselle word as van dieselfde morfologiese tipe beskou.

Ray cell, square ${ }^{*}(\mathrm{E}) \quad$ Straalcel, vierkante ${ }^{*}(\mathrm{~N})$ Markstrahlzelle, Quadratische *(D)

\section{STRAALTRAGEÏED (152)}

'n Trageïed wat deel vorm van 'n straal en wat gevolglik radiaal verloop.

Ray tracheid ${ }^{*}(\mathrm{E}) \quad$ Straaltracheïde ${ }^{*}(\mathrm{~N}) \quad$ Markstrahltracheiden ${ }^{*}(\mathrm{D})$

\section{TEËLVORMIGE SEL (177)}

'n Besondere tipe straalsel wat aksiaal en tangensiaal ongeveer dieselfde afmetings as ' $n$ neerliggende sel het, maar wat radiaal heelwat korter is. Kom onbepaald in horisontale reekse tussen neerliggende selle voor.

Tile cell *(E) Tegelvormige cel ${ }^{*}(\mathrm{~N})$ Ziegelzelle *(D)

\section{TIL (186)}

'n Uitstulping van 'n aangrensende straalsel, of 'n aksiale parenchiemsel, wat deur 'n houtvatstippel in die houtvat ingroei. Dit verstop hout vate gedeeltelik of totaal. Opmerking: Tille kan yl verspreid of teen mekaar voorkom, dik- of dunwandig wees, met of sonder stippels wees en kristalle, stysel, gom- of harsinhoude hê.

Tylosis pl. tyloses *(E) Thyllen *(N) Thylle*(D)

\section{TIL, SKLEROTIESE (187)}

'n Til met 'n buitengewone dik, gelignifiseerde en gelaagde wand waarin ook vertakte stippelkanale in voorkom (sien STEENSEL).

Tylosis, sclerotic ${ }^{*}(\mathrm{E}) \quad$ Thyllen, sklerotische ${ }^{*}(\mathrm{~N})$ Thylle, Stein- ${ }^{*}(\mathrm{D})$

\section{TILL.OSOÏED (188)}

'n Uitstulping van 'n dunwandige epiteel in ' $n$ intersellulêre kanaal. Opmerking: Onderskeibaar van tille deurdat dit nie deur 'n stippelkanaal gegroei het nie.

Tylosoid ${ }^{*}(\mathrm{E}) \quad$ Thyllosoïde *(N) Thylosoid ${ }^{*}(\mathrm{D})$

\section{TORLS Sien STIPPELMEMBRAAN}

\section{TRABEKLLA (178)}

'n (jelignifiseerde stafie wat radiaal oor die lumen van 'n trageied of ' $n$ houtvat strek. Soms beperk tot ' $n$ enkele trageïed, soms in opeenvolgende trageïede.

Trabecula(e) *(E) Trabecula(e) *(N) Trabekel *(D)

\section{TRAGEA Sien HOUTVAT}

\section{TRAGEALE ELEMENTE (179)}

Die belangrikste elemente in die xileem vir vervoer van water, nl. houtvate en trageïede. Opmerking: In die proto- en metaxileem besit hierdie elemente altyd ring-, spiraal- of netvormige verdikkings.

Tracheary elements * $(E)$ Tracheale elementen $*(N)$ Tracheale Elemente *(D)

\section{TRAGEÏED (180)}

'n Aksiale xileemelement waarvan beide ente toe is en wat anders as houtvatelemente nooit 'n perforasieplaat het nie. Deur middel van hofstippels met kongeneriese elemente verbind.

Tracheid ${ }^{*}(\mathrm{E}) \quad$ Tracheïde ${ }^{*}(\mathrm{~N}) \quad$ Tracheide ${ }^{*}(\mathrm{D})$

\section{TRAGEÏED, DISJUNKTE (181)}

Trageïede wat tydens differensiasie sywaarts, gedeeltelik van mekaar geskei word. Kontak tussen hierdie selle is deur middel van buisvormige uitgroeisels.

Tracheid, disjunctive ${ }^{*}(E)$ Tracheïde, disjuncte *(N) Tracheide, Joch- *(D)

\section{TRAGEÏED, STRING- (183)}

'n Trageïed van 'n aksiale string wat net uit trageïede bestaan, of 'n gemengde string wat uit sowel trageiede as parenchiemselle bestaan. Elke string ontwikkel egter uit 'n enkele kambiuminisiaal (vergelykbaar met 'n parenchiemstring).

Tracheid, strand ${ }^{*}(\mathrm{E})$ Tracheïde, streng- * $(\mathrm{N})$ Tracheide, Strang- *(D)

\section{TRAGEÏED, VAT- (184)}

'n Aksiale element wat 'n groot ooreenkoms toon met 'n houtvatelement behalwe dat dit smaller is en teenaan 'n houtvat aangetref word. Kan geen of slegs een perforasieplaat hê.

Tracheid, vascular ${ }^{*}(\mathrm{E})$ Tracheïde, vat- ${ }^{*}(\mathrm{~N})$ Tracheide, Gefäss- ${ }^{*}(\mathrm{D})$

\section{TRAGEÏED, VASISENTRIES (185)}

in Kort. onreëlmatig gevormde trageïed in die onmiddellike omgewing van 'n houtvat, wat self nie deel van 'n aksiale reeks selle is nie.

Tracheid, vasicentric *(E) Tracheïde, vasicentrische ${ }^{*}(\mathbf{N}) \quad$ Tracheide. Vasizentrische ${ }^{*}(\mathrm{D})$

\section{TRALMATIESE RING (160)}

in Sone traumatiese weefsel wat gevorm is deur ' $n$ beskadigde kambium. Opmerking: Algemene oorsake is ryp, droogte en vuur. Die weefsel sluit onreëlmatig gevormde wondparenchiem in en kan as gevolg van die teenwoordigheid van gomme en harse donker gekleur wees. Soms is daar intersellulêre kanale en deur droogte gevormde skeure, aanwesig. Hierdie ringe kan as ryp- of droogteringe bekend staan. mits die oorsaak daarian bekend is.

Ring, traumatic * $(E)$ Traumatische ring $*(N)$

Wundrmg *(D) 


\section{VAATKAMBIUM}

'n Aktief delende laag selle wat deur periklinale delings aan sekondêre vaatweefsels oorsprong gee. Word uit die prokambium gevorm.

\section{VAATKAMBIUM, GESTRATIFISEERDE (10)}

'n Vaatkambium waarin beide spoel- en straalinisiaalselle, soos gesien in tangensiale sneë, in duidelik horisontale rye gerangskik is.

Cambium, storied $*(E)$ Cambium, etage- $*(N)$

Kambium, Stockwerk- *(D)

\section{VERBINDINGSWEEFSEL (15)}

'n Spesiale tipe parenchiem wat geassosieerd met ingeslote floëem voorkom.

Conjunctive tissue ${ }^{*}(\mathrm{E}) \quad$ Verbindingsweefsel ${ }^{*}(\mathrm{~N})$ Verbindungsgewebe ${ }^{*}(\mathrm{D})$

\section{VESEL (32)}

In houtanatomie 'n algemene term vir lang, smal selle in hout en bas. Sluit nie houtvate en parenchiem in nie. Opmerking: Soms meer spesifiek gebruik vir hout- en basvesels. Met die term xileemvesel word spesifiek verwys na librivormige vesels van houtagtige Angiospermae. In 'n tegnologiese sin, soos in die Pulp en Papierbedryf, word die term vir alle xileemelemente, insluitend die aksiale trageïede van die hout van Gymnospermae gebruik.

Fibre, fiber $(\mathrm{Am}.){ }^{*}(\mathrm{E}) \quad$ Vezel ${ }^{*}(\mathrm{~N})$ Faser $*(\mathrm{D})$

VESEL, BAS- (33)

'n Vesel in die floëem of buitenste weefsel.

Fibre, bast ${ }^{*}(\mathrm{E})$ Vezel, bast- ${ }^{*}(\mathrm{~N})$ Faser, Bast*(D)

\section{VESEL, GELATIENAGTIGE (34)}

'n Vesel met ' $n$ min of meer ongelignifiseerde binnewand en met 'n gelatienagtige voorkoms (sien HOUT, TREK-).

Fibre, gelatinous ${ }^{*}(\mathrm{E})$ Vezel, gelatineuze ${ }^{*}(\mathrm{~N})$ Faser Gelatinöse *(D)

\section{VESEL, GESEPTEERDE HOUT- (36)}

'n Vesel met dun dwarswande oor die lumen. Opmerking: In hierdie elemente verdeel die protoplas nadat die sekondêre selwand gevorm is.

Fibre. septate wood ${ }^{*}(\mathrm{E})$ Vezel, gedeelde hout-

${ }^{*}(\mathrm{~N})$ Faser, Gefächerte (gekammerte) ${ }^{*}(\mathrm{D})$

\section{VESEL, LIBRIVORMIGE HOLT- (35)}

'n Aksiale. lang, meestal dikwandige sel met gewoonlik eenvoudige stippels of as uitsondering. hofstippels met 'n baie klein hof. Gewoonlik opvallend langer as die kambiuminisiaal in soverre dit afgelei kan word van die lengte van houtvatelemente en parenchiemstringe (sien XIL.EEMVESEL).

Fibre, libriform wood ${ }^{*}(E)$ Vezel. libriform- ${ }^{*}(\mathbf{N})$

Faser, Libriform- ${ }^{*}(\mathrm{D})$

\section{VESEL, HOLT-Sien XILEEMIVESEI.}

\section{VESELTRAGEÏED (38)}

'n Dikwandige trageïed wat soos 'n vesel lyk. Dikwels met 'n klein lumen en spits punte, hofstippelpare met lensvormige, versonke of uitstaande stippelopeninge. Het sowel 'n vervoer- as meganiese steunfunksie. Hierdie term word gebruik vir trageiede in díe laathout van Gymnospermae-houtsoorte asook vir veselvormige trageïede in Angiospermae-houtsoorte.

Fibre-tracheid *(E) Vezeltracheïde *(N) Fasertracheide $*(D)$

\section{VESELTRAGEÏED, GESEPTEERDE (182)}

'n Veseltrageied waarvan die lumen deur dun dwarswande onderverdeel is. Opmerking: In hierdie elemente deel die protoplas nadat sekondêre wande gevorm is.

Tracheid, septate fibre- ${ }^{*}(\mathrm{E})$ Vezeltracheïde, gedeelde ${ }^{*}(\mathrm{~N})$ Fasertracheide, Gefächerte (gekammerte) ${ }^{*}(\mathrm{D})$

\section{XILEEM (192)}

Die belangrikste weefsel in blare, stingels en wortels vir die vervoer van water en minerale stowwe asook vir die verlening van meganiese sterkte aan organe. Bestaan uit trageale elemente (houtvate en trageïede), xileemvesels, aksiale parenchiem en xileemstrale. Sinoniem: HOUT.

$$
\text { Xylem } *(E) \quad \text { Xyleem *(N) Xylem *(D) }
$$

\section{XILEEM, META-Sien METAXILEEM.}

XILEEM, PRIMÊRE- (204)

Xileem wat uit die apikale meristeem (prokambiumstringe) gedifferensieer het. Eerste gevormde xileem. Opmerking: Gewoonlik aan die rand van stingel se murg geleë.

Xylem, primary $*(\mathrm{E}) \quad$ Xyleem, primair $*(\mathrm{~N})$ Xylem Primäres *(D)

\section{XILEEM, PROTO- Sien PROTOXYLEEM.}

\section{XILEEM, SEKONDÊRE (205)}

Hout wat deur die vaatkambium gevorm is.

Xylem, secondary ${ }^{*}(\mathrm{E})$ Xyleem, secundair ${ }^{*}(\mathrm{~N})$ Xylem, Sekondäres *(D)

\section{XILEEMMOEDERSEL (206)}

'n Sel wat aan die binnekant van die spoelvormige kambiuminisiaal "afgesny" is en wat verdere periklinale seldeling ondergaan het voordat dit in 'n xileemsel gedifferensieer het.

Xylem mother cell $*(E)$ Xyleemmoedercel ${ }^{*}(\mathrm{~N})$ Xylem-Mutterzelle *(D)

\section{XILEEMVESEL (37)}

'n Vesel wat in die xileem voorkom en wat deel van die xileem is (sien VESEL, LIBRIVORMIGE HOUT-). Fibre, libriform ${ }^{*}(\mathrm{E})$ Houtvezel ${ }^{*}(\mathrm{~N})$ Faser, Hol $\%$ *(D) 